\title{
Evaluation of mild acute infectious myocarditis
}

\author{
JUHANI HEIKKILA, JOUKO KARJALAINEN \\ From the First Department of Medicine, University Central Hospital, Helsinki, and the Central Military Hospital 1, \\ Helsinki, Finland
}

SUMMARY The diagnosis of acute mild myocarditis is vaguely defined. Therefore we studied 185 consecutive young men in military service with electrocardiographic changes arousing a suspicion of myocarditis in connection with an acute infectious disease. It was possible to classify 160 patients into seven electrocardiographic groups; definite or probable myocarditis was observed in 104 patients. The electrocardiographic patterns considered characteristic for acute myocarditis were: ST segment elevations followed by $T$ wave inversions; gradually changing $T$ wave inversions not corrected by beta blockade; and ventricular extrasystoles more than 10 per minute triggered by acute infection. Thirty-nine subjects without myocarditis had "functional" $T$ wave abnormalities completely normalised by beta blockade, or stable $\mathrm{T}$ wave inversions.

The leading symptoms in acute myocarditis were fatigue and chest pains; loud $\mathrm{S}_{3}$ gallop, paradoxical cardiac pulsation, pericardial friction rub, or enlargement of the heart were noted altogether in $50 \%$ of the patients. Echocardiography disclosed segmental wall motion abnormalities related to the $T$ wave inversions. Serum creatine kinase MB fraction increased in $70 \%$ of the acute myopericarditis patients during the ST segment elevation stage. In the non-myocarditis groups the clinical and pertinent laboratory findings remained normal.

Thus, we noted in clinically mild acute infectious myocarditis clear-cut and early signs of myocardial dysfunction, suggesting that the direct and often local viral invasion of the myocardium is the basic pathogenetic mechanism. The present electrocardiographic classification based on serial tracings and beta blockade proved usetul in the evaluation of patients suspected of having mild acute myocarditis.

Severe acute myocarditis does not usually give rise to diagnostic difficulties, since gross cardiac enlargement and often progressive heart failure are clinically selfevident. Such a course of infectious myocarditis is rare. ${ }^{1}$ In contrast, mild often clinically asymptomatic myocarditis is common. ${ }^{2}$ Diagnosing even mild acute myocarditis is necessary, as these patients may be in danger of sudden cardiac death, ${ }^{3}$ or may insidiously develop congestive cardiomyopathy. ${ }^{4}$

Diagnosing subclinical viral myocarditis depends essentially on an electrocardiogram at the initial stage of the disease. ${ }^{2} 5$ It is, however, also obvious that

functional electrocardiographic abnormalities noted in connection with acute infectious disease and fever, and changes caused by other cardiac disease should not necessarily indicate acute myocardial involvement. ${ }^{6} 7$

Supported in part by the Finnish Foundation for Cardiovascular Research, the Yriö Jahnsson Foundation, and the Paavo Nurmi Foundation.

Accepted for publication 22 October 1981
This report reviews our experience with the clinical evaluation of patients with various electrocardiographic abnormalities arousing a suspicion of acute myocarditis in conjunction with, for example, an acute respiratory or gastroenteric infection. We particularly intend to propose an electrocardiographic classification, which we have found useful in the evaluation of patients in whom mild acute myocarditis may be present.

\section{Methods}

PATIENTS

One hundred and eighty-five patients were thoroughly examined at Central Military Hospital 1 in Helsinki. The patients were either conscripts in compulsory military service or young military personnel 18 to 38 years old, median age 20 years. They had been admitted because of electrocardiographic abnormalities which were noted in the course of an acute infectious 
disease. This consecutive series was collected during the period December 1976 to December 1980. There were two different ways of including patients in the study series: (1) Patients whose electrocardiograms were recorded because of clinical symptoms or signs possibly related to acute myocarditis or pericarditis (63\% of the study population); (2) patients taken for a prospective study (37\% of the study population) initiated in January 1978 to examine the incidence and clinical picture of acute mild myocarditis in connection with respiratory or gastrointestinal infection, irrespective of any cardiac symptoms. In three garrisons, a 12 lead electrocardiogram was recorded from all conscripts with acute infective symptoms, as partially reported previously. ${ }^{5}$ In the prospective series an electrocardiogram was recorded on the first and third days of the disease, and two weeks later.

Each patient was clinically examined within two weeks of the initial electrocardiographic changes. The follow-up time was two to 12 months after the acute stage and always lasted until the electrocardiogram reverted to normal, or up to 12 months after the acute stage in the case of permanent electrocardiographic abnormalities.

\section{CLINICAL SYMPTOMS AND SIGNS}

Chest pain was recorded as being extracardiac, pericardial, or mimicked coronary pain. The patients were asked about other subjective symptoms, such as palpitations.

A physical examination was made by both authors; particular attention was paid to palpation of the cardiac thrust and to auscultation. The cardiac palpation was classified as follows: normal apical beat only, uncertain asynergic contraction, or distinct paradoxical precordial motion. The $\mathrm{S}_{3}$ gallop was classified as none, weak and disappearing in the sitting position, or loud, also in the sitting position. This positional analysis was thought to help in separating the normal ventricular rapid filling sound present in young subjects with hyperkinetic circulation (physiological $\mathrm{S}_{3}$ ) from sounds in those with myocardial involvement.

\section{LABORATORY EXAMINATIONS}

Serial 12 lead electrocardiograms were usually recorded daily during the first week of the acute illness and thereafter at one to two week intervals until the ST-T changes reverted to normal. The method of classification for the electrocardiograms is presented in the results. The beta blockade test was performed to differentiate the $T$ wave inversions caused by acute myocarditis or some other organic cause from "functional" $T$ wave inversions. ${ }^{7}$ An electrocardiogram was recorded supine at rest and after standing for three minutes, and was repeated two hours after the oral administration of the beta-blocking drug, usually $100 \mathrm{mg}$ metoprolol. The test was considered adequate if the heart rate at rest decreased by $10 \%$ or more. Chest $x$-rays and serial echocardiograms ${ }^{8}$ were taken in all patients.

Positive serological findings indicating a viral or other specific infectious cause of the acute illness were found in $47 \%$ of the myocarditis patients. These will be published separately; aetiology was viral in $80 \%$ of the patients, the three most common agents being adeno, influenza, and vaccinia virus.

The patients' serum creatine kinase (normal level $<220 \mathrm{IU} / \mathrm{l}$ ), aspartate aminotransferase, and alanine aminotransferase (normal levels $<40 \mathrm{U} / 1$ for both) were determined: in 65 of 160 patients this was possible during the first week of the infectious disease. The creatine kinase isoenzymes were assessed electrophoretically and quantified by fluorometric scanning, using the method of Somer and Konttinen'; 0.03 of total creatine kinase was taken as upper limit of normal.

\section{Results}

ELECTROCARDIOGRAPHIC CLASSIFICATION OF STUDY POPULATION

Of the 185 consecutive patients 160 could be classified into the following seven groups, based on serial resting electrocardiograms and on the response of the ST-T waves to beta adrenergic blocking drugs. Diagnosis of definite or probable acute myocarditis, or no myocarditis, was based on serial electrocardiographic data only, as described below.

\section{Definite myocarditis (groups 1 and 2)}

Myopericarditis: group 1: the serially changing electrocardiographic ST segment and T wave alterations were characteristic of the well-established abnormalities of "acute pericarditis". ${ }^{10}$ The initial ST segment elevation of $0.1 \mathrm{mV}$ or more in several leads is gradually replaced in this group by an inversion of the T waves (Fig. 1).

The ST segment elevations were noted in 34 patients and were widely distributed in $56 \%$ of the patients. The subsequent $T$ wave inversions taking place in these patients, however, were usually only local, $88 \%$ (Table 1). The gradual changes in the ST segment elevations and $T$ wave inversions generally had a duration of six to eight weeks, the initial ST segment elevation returning to normal in one week.

The beta blockade test was performed in 15 patients at the $T$ wave inversion stage. No patient showed less $\mathrm{T}$ wave inversion after beta blockade; it often became more prominent (Fig. 2). During late convalescence, however, functional-type, vacillating $\mathrm{T}$ wave variations were also commonly noted before 
Characteristic sequential electrocardiographic ST-T patterns

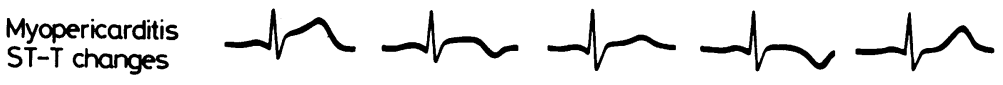

Fig. 1 Schematic representation of serial ST-T patterns of myopericarditis, myocarditis, and non-myocarditis states.

Myocarditis gradual T wave

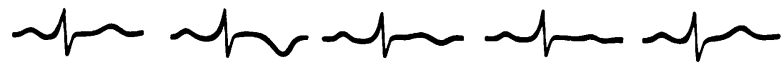
changes

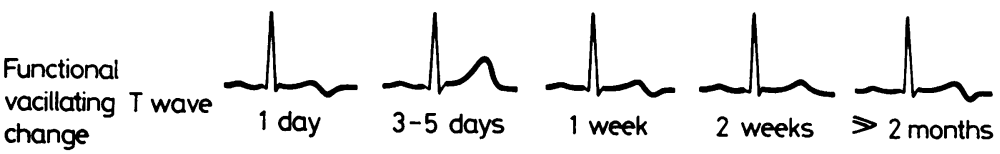

Table 1 Site and duration of ST-T changes in 34 patients with myopericarditis (group 1) and 22 patients with myocarditis (group 2)

\begin{tabular}{|c|c|c|c|c|c|}
\hline \multicolumn{3}{|l|}{ Site } & \multicolumn{3}{|l|}{ Duration } \\
\hline \multirow[t]{2}{*}{ Electrocardiographic lead } & \multicolumn{2}{|c|}{ No. of cases } & \multirow[t]{2}{*}{ Mean days } & \multicolumn{2}{|l|}{ No. of cases } \\
\hline & $S T \uparrow$ & $T \downarrow$ & & $>1$ month & $<1$ month \\
\hline $\begin{array}{l}\text { General: I, II, III, aVL, aVF, V3-6 } \\
\text { Myopericarditis ST-T changes } \\
\text { Myocarditis T wave changes } \\
\text { Inferoapical: II, III, aVF, V3-6 }\end{array}$ & 19 & $\begin{array}{l}4 \\
1\end{array}$ & $\begin{array}{r}34 \\
5\end{array}$ & 3 & $\begin{array}{l}1 \\
1\end{array}$ \\
\hline $\begin{array}{l}\text { Myopericarditis ST-T changes } \\
\text { Myocarditis T wave changes } \\
\text { Anterolateral: I, II, aVL, V3-6 }\end{array}$ & 9 & $\begin{array}{l}19 \\
15\end{array}$ & $\begin{array}{l}47 \\
17\end{array}$ & $\begin{array}{r}15 \\
3\end{array}$ & $\begin{array}{r}4 \\
12\end{array}$ \\
\hline $\begin{array}{l}\text { Myopericarditis ST-T changes } \\
\text { Myocarditis T wave changes }\end{array}$ & 6 & 11 & $\begin{array}{l}45 \\
53\end{array}$ & $\begin{array}{l}9 \\
3\end{array}$ & $\begin{array}{l}2 \\
2\end{array}$ \\
\hline
\end{tabular}

$\star$ One patient had anteroseptal $\mathrm{T}$ wave inversions in V2-4.

the permanent return to normal of the electrocardiogram.

Myocarditis T wave inversion: group 2: the 22 patients included in this group had a pattern of gradually changing $T$ waves in at least two leads, excluding leads $a$ VR and $V_{1}$ where the $T$ wave may be normally negative. First there was a gradual inversion of the $T$ waves and subsequently their gradual return to normal. The $T$ wave inversions had to last four days or more. An equivalent change was considered to have taken place if the $T$ waves were already initially maximally inverted but thereafter showed a pattern of gradual return to normal. In this group it was also necessary that these gradual $\mathrm{T}$ wave inversions did not improve after an effective dose of beta-blocking drug, as described in the methods.

$\mathrm{T}$ wave inversions were located in the inferoapical region in the majority of patients (68\%), while anterolaterally located changes showed the longest duration (Table 1). The most characteristic sequence of the electrocardiographic abnormalities was an almost simultaneous inversion of the $T$ waves in leads II, III, aVF, and V4-6 to maximum negativity as early as days one to three of the infection. Thereafter the gradual return to normal always followed the same sequence: the chest leads first reverted to normal, followed by leads II and aVF, and finally lead III (Fig. 2).

\section{Probable myocarditis (groups 3 and 4)}

Probable myocarditis $T$ wave inversion: group 3: 34 patients showed a pattern of gradual $T$ wave changes similar to that described in group 2; in fact the only difference was that no confirming beta blockade test was available for this group.

Ventricular extrasystoles of recent onset: group 4: ventricular extrasystoles were first noted during, or soon after, an acute infection as a presenting symptom in 

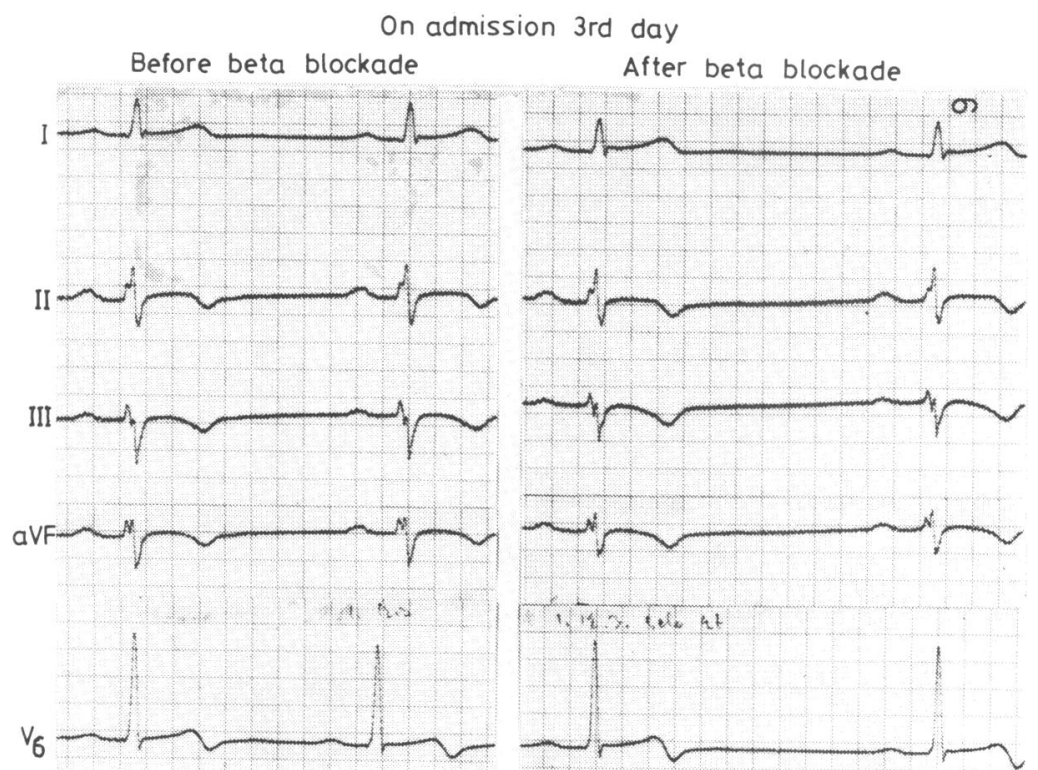

Fig. 2 Characteristic sequence of the gradually changing inferoapical $T$ wave inversion.

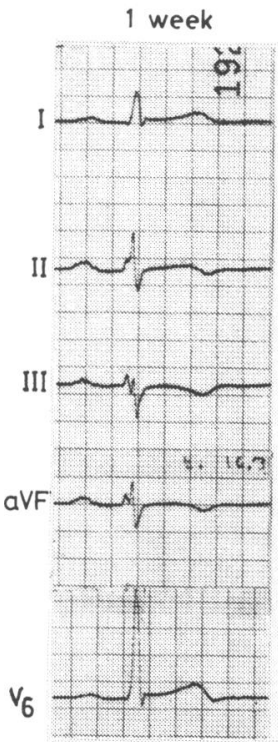

2 weeks

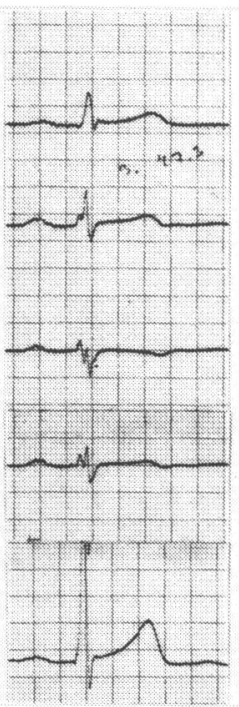

6 weeks
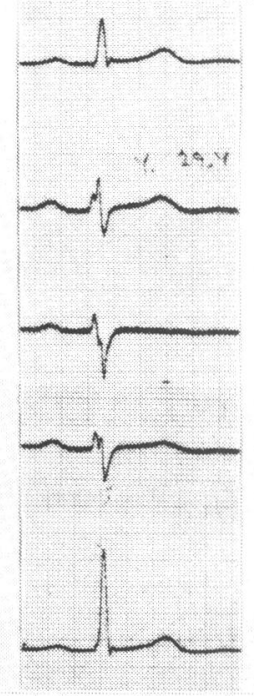

2 months

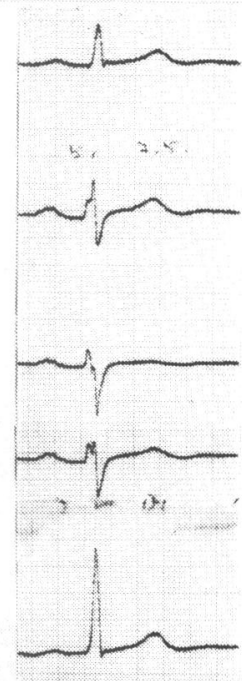

this group, and the serial electrocardiograms showed no pronounced ST-T changes. Extrasystoles had an occasional frequency of at least 10 beats per minute. Further, the patient himself had to feel that this cardiac irregularity was a new symptom.

The ventricular extrasystoles were, with only one exception, unifocal and septal in origin. In four of the 14 patients included in this group, the mechanism was unequivocally parasystolic; two patients experienced ventricular tachycardia. In 11 of the 14 patients (79\%) the ventricular extrasystoles either increased in frequency (nine patients) or else were not changed by the bicycle exercise test. The arrhythmias lasted less than two months in three patients; the others had extrasystoles throughout the follow-up periods of three to 10 months. Five patients also had gradually changing minor $\mathrm{T}$ wave inversions for up to two weeks at the initial stage of the disease. 
Short-term myocarditis-type $T$ wave inversions: group 5 The 17 patients included in this electrocardiographic group had a gradual $\mathrm{T}$ wave inversion pattern during an acute infection. These $T$ wave inversions, however, were present for only one to three days and no beta blockade test was available. No "functional", "vacillating" $T$ wave behaviour was noted. All but one of the $T$ wave inversions were local: eight inferoapical and eight local anterior in leads V2, V3, and/or V4.

\section{Patients without myocarditis (group 6 and 7)}

"Functional" $T$ wave changes: group 6: the alterations in the $T$ waves did not show the gradually changing pattern in the serial electrocardiograms described above, but instead vacillated irregularly between a normal and an abnormal shape. This group included 25 patients initially suspected of having acute myocarditis. The $T$ wave abnormality was augmented without exception during the standing position and often during sinus tachycardia in supine rest. Even when the resting tracing was normal, the "vasoregulatory" $T$ wave inversions were always generated orthostatically. These "vacillating", "functional", or "vasoregulatory" $T$ wave inversions returned completely to normal as a result of beta blockade. $T$ wave inversions of this type were never seen in leads I and aVL. The functional T wave inversions were present only during fever in some patients, while in others this fluctuation was permanent.

Stable $T$ wave inversions: group 7: permanently negative $T$ waves, without clinical signs of acute myocarditis, were noted in 14 patients. Such T waves did not show any gradually changing patterns though minor variations in the amplitudes of the negative $T$ waves were possible. Beta blockade either enhanced the $T$ negativity or else did not have any influence on it. Some of these patients had aortic valve disease or cardiomyopathy; in most, no definite organic cardiac pathology was found.

\section{Exclusions}

Of the 185 subjects included in the present study population in connection with an acute infection, 25 were excluded from the seven electrocardiographic groups defined above. Three patients may have had mild myocarditis, one of them developed a new right bundle-branch block and prolongation of the $P Q$ interval, while two had ST depressions only during the bicycle exercise test. The other findings were: early repolarisation-type ST segment elevation (10 subjects), supraventricular arrhythmias (four), functional $T$ wave changes, not included in group 6 because the beta-blockade test remained insufficient (three), sport heart (two), ventricular extrasystoles of long duration (one), mitral valve prolapse (one), and hypertrophic obstructive cardiomyopathy (one).

\section{Data provided by prospective electrocardiographic screening}

Only a few patients with the myopericarditis type of electrocardiogram (group 1) or with ventricular extrasystoles of recent onset (group 4) were identified in the prospective screening (Table 2). The majority of the subjects with "functional" $T$ wave changes (group 6) were naturally detected by this screening method.

It is worth noting that all the patients who had electrocardiographic findings, which mainly pointed to definite or probable myocarditis, already showed these changes in tracings taken on the first and/or third day of the onset of the infectious disease.

\section{CLINICAL FEATURES RELATED TO}

ELECTROCARDIOGRAPHIC CLASSIFICATION

The occurrence of the symptoms and physical findings in the different patient groups is summarised in Table 3. Clinically clear-cut myopericarditis was usuaily caused by vaccinia, mononucleosis, mycoplasma, chlamydia, and Coxsackie B4 infections. Adenovirus and influenza myocarditis were most often only detected by serial electrocardiographic screening.

Table 2 Distribution of patients with various electrocardiographic presentations; 59 of 160 patients (37\%) emerged from prospective screening of patients with infection

\begin{tabular}{|c|c|c|c|c|c|c|c|}
\hline Group & 1 & 2 & 3 & 4 & 5 & 6 & 7 \\
\hline$E C G$ definition & $\begin{array}{l}\text { Myoperi- } \\
\text { carditis }\end{array}$ & \multicolumn{2}{|c|}{$\begin{array}{l}\text { Myocarditis-type } \\
T \text { wave inversions }\end{array}$} & $\begin{array}{l}\text { Extrasystoles } \\
\text { related to } \\
\text { infection }\end{array}$ & $\begin{array}{l}\text { Short-term } \\
T \text { wave } \\
\text { inversions }\end{array}$ & $\begin{array}{l}\text { Functional } \\
T \text { wave } \\
\text { changes }\end{array}$ & $\begin{array}{l}\text { - Stable } \\
\text { Twave } \\
\text { inversions }\end{array}$ \\
\hline $\begin{array}{l}\text { Diagnosis of myocarditis } \\
\text { Total no. of patients } \\
\text { Prospective screening (\%) }\end{array}$ & $\begin{array}{l}\text { Definite } \\
34 \\
2(6)\end{array}$ & $\begin{array}{l}\text { Definite } \\
22 \\
11(50)\end{array}$ & $\begin{array}{l}\text { Probablet } \\
34 \\
15(44)\end{array}$ & $\begin{array}{l}\text { Probable } \\
14 \\
1(8)\end{array}$ & $\begin{array}{l}\text { Possible } \\
17 \\
8(47)\end{array}$ & $\begin{array}{l}\text { Noł } \\
25 \\
19(76)\end{array}$ & $\begin{array}{l}\mathrm{No}^{\star} \\
14 \\
3(21)\end{array}$ \\
\hline
\end{tabular}

$\star$ Beta blockade did not normalise inverted $\mathrm{T}$ waves.

†Beta blockade test not performed.

$¥$ Beta blockade normalised the inverted $\mathrm{T}$ waves. 
Table 3 Symptoms and signs in 160 patients of study series

\begin{tabular}{|c|c|c|c|c|c|c|c|}
\hline Group no. & $l$ & 2 & 3 & 4 & 5 & 6 & 7 \\
\hline Total no. of patients & 34 & 22 & 34 & 14 & 17 & 25 & 14 \\
\hline $\begin{array}{l}\text { Fatigue } \\
\text { Pain }\end{array}$ & 15 & 7 & 12 & 11 & 4 & 6 & 4 \\
\hline $\begin{array}{l}\text { None } \\
\text { Extracardiac } \\
\text { Pericardial } \\
\text { Coronary mimicking }\end{array}$ & $\begin{array}{r}8 \\
5 \\
14 \\
7\end{array}$ & $\begin{array}{r}12 \\
5 \\
4 \\
1\end{array}$ & $\begin{array}{r}25 \\
3 \\
4 \\
2\end{array}$ & $\begin{array}{l}8 \\
2 \\
2 \\
2\end{array}$ & $\begin{array}{r}10 \\
4 \\
1 \\
2\end{array}$ & $\begin{array}{r}15 \\
8 \\
1 \\
1\end{array}$ & $\begin{array}{l}9 \\
4 \\
1 \\
0\end{array}$ \\
\hline $\begin{array}{l}\text { Palpation } \\
\text { Normal } \\
\text { Borderline } \\
\text { Paradoxical } \\
\text { S3 }\end{array}$ & $\begin{array}{l}12 \\
11 \\
11\end{array}$ & $\begin{array}{r}13 \\
3 \\
6\end{array}$ & $\begin{array}{r}21 \\
7 \\
6\end{array}$ & $\begin{array}{l}5 \\
6 \\
3\end{array}$ & $\begin{array}{r}11 \\
5 \\
1\end{array}$ & $\begin{array}{r}21 \\
4 \\
0\end{array}$ & $\begin{array}{r}12 \\
1 \\
1\end{array}$ \\
\hline $\begin{array}{l}\text { None } \\
\text { Physiological } \\
\text { Abnormal } \\
\text { S4 }\end{array}$ & $\begin{array}{r}10 \\
7 \\
17\end{array}$ & $\begin{array}{r}15 \\
3 \\
4\end{array}$ & $\begin{array}{r}15 \\
10 \\
9\end{array}$ & $\begin{array}{l}7 \\
4 \\
3\end{array}$ & $\begin{array}{l}9 \\
5 \\
3\end{array}$ & $\begin{array}{r}11 \\
13 \\
1\end{array}$ & $\begin{array}{l}9 \\
3 \\
1\end{array}$ \\
\hline $\begin{array}{l}\text { Present } \\
\text { Pericardial rub }\end{array}$ & 2 & 0 & 0 & 0 & 0 & 0 & 0 \\
\hline $\begin{array}{l}\text { Present } \\
\text { Heart size }\end{array}$ & 10 & 4 & 5 & 0 & 0 & 0 & 0 \\
\hline Enlarged & 7 & 2 & 8 & 6 & 1 & 0 & 0 \\
\hline
\end{tabular}

Exceptional fatigue continuing after the initial stage of the infection appeared to be more common (38\%) in the patients with myocarditis (groups 1 to 3 ) than in groups 6 to 7 (26\%) with no myocarditis. The patients with recent ventricular extrasystoles felt prolonged fatigue very often (79\%). The pericardial type of chest pain and "coronary mimicking" pain were most common in the myopericarditis group $(41 \%$ and $21 \%$, respectively).

A pathological cardiac palpatory finding was noted in $25 \%$ of patients with definite or probable acute myocarditis; a borderline abnormal finding was noted in a further $26 \%$. The paradoxical cardiac thrust did not have as high an amplitude as is found in acute myocardial infarction, but it was commonly pansys-

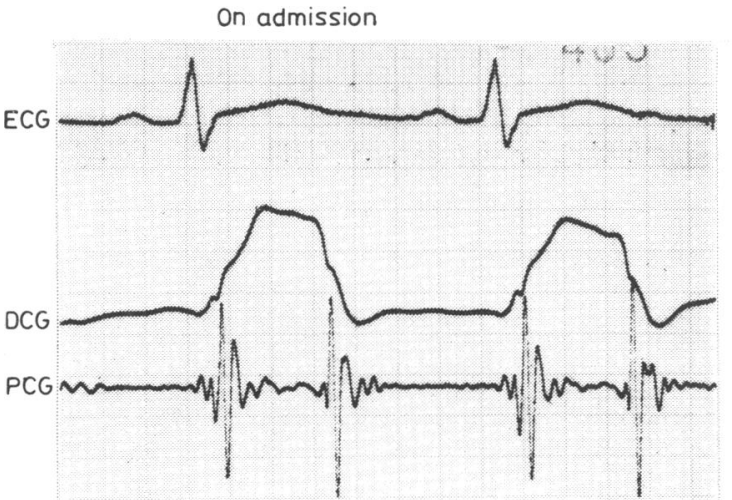

tolic (Fig. 3). It was an initial physical finding; in only two patients did it appear two weeks after the first electrocardiographic findings. An $\mathrm{S}_{3}$ gallop was a frequent auscultatory finding (52\%). In the myocarditis groups the $\mathrm{S}_{3}$ gallop was frequently loud and also persisted in the sitting position $(30 \%$ of the 104 patients); it was rare (5\%) in the 39 patients without myocarditis. A pericardial rub was heard only in patients with the ST and/or T wave changes classified as indicating myopericarditis or myocarditis. A rub was heard in $29 \%$ of the patients with ST segment elevations, and in $16 \%$ of the patients with gradual $\mathrm{T}$ wave changes. No patient in this series of infectious myocarditis developed congestive heart failure.

Altogether, one or several findings of a loud $\mathrm{S}_{3}$ gallop, cardiac palpatory asynergy, or pericardial rub was present in 52 of the 104 patients in the myocarditis groups 1 to 4 .

\section{CHEST X-RAYS}

The cardiac size was normal and did not show any enlargement in the hospital follow-up in the nonmyocarditis patients (groups 6 and 7). The heart became enlarged in only one of the 17 patients in group 5 with short-term $\mathrm{T}$ wave changes. An abnormal heart size was seen in $22 \%$ of the 104 myocarditis patients (groups 1 to 4 ). Notably, this abnormality occurred most often in the ventricular arrhythmia group: in six of the 14 patients (43\%). Conspicuous pulmonary venous congestion did not occur in these patients.

\section{SERUM ENZYMES}

Serum aspartate aminotransferase activity was increased during the first week only in the patients with myopericarditis ST segment changes (Fig. 4).

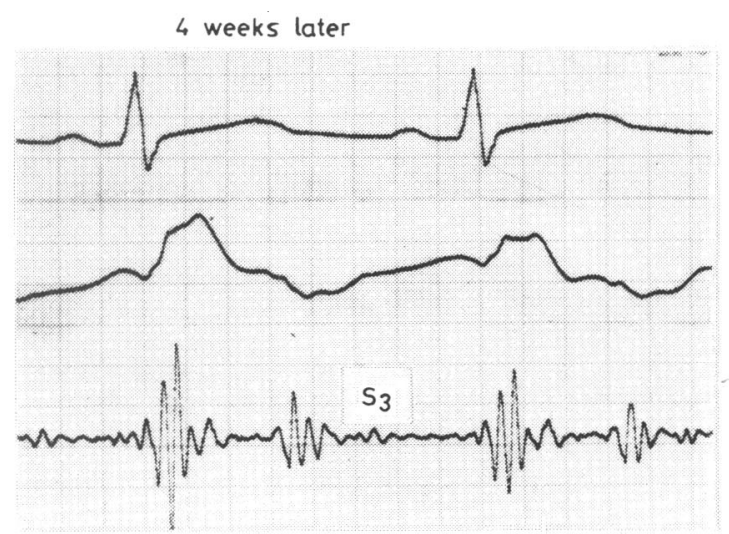

Fig. 3 Kinetocardiogram in an acute stage of myocarditis, confurming the palpable paradoxical cardiac pulsation. This method of recording the precordial displacement curve gives absolute precordial motion, not relative motion as with the apexcardiogram. The normal curve is mainly negative. Four weeks later the asynergic motion is less. Note also the third sound. 


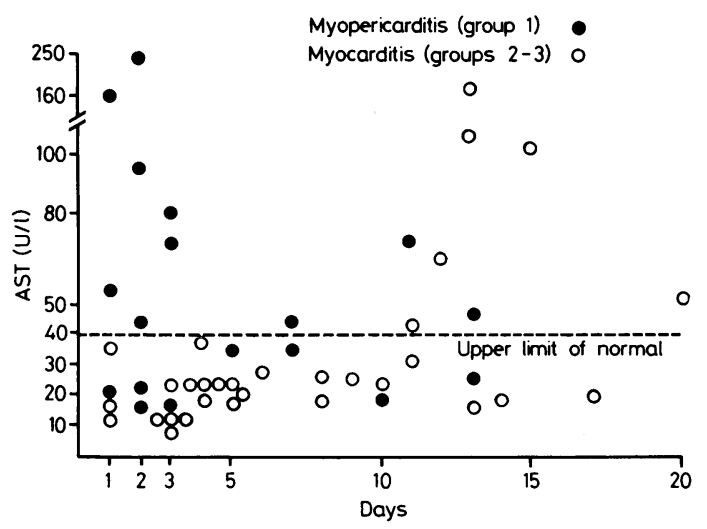

Fig. 4 Serum aspartate aminotransferase (AST) elevations were noted only during the initial days in the patients with myopericarditis but not in those with myocarditis-type $T$ wave changes only. After the first week, however, new increases were noted, probably reflecting hepatic involvement.

The highest values were noted in those patients who also had the highest creatine kinase MB (CK MB) levels. Abnormal values lasting over the first week of the disease were noted in nine patients and only if alanine aminotransferase was increased at the same time; this late increase was observed also in some patients with $T$ wave changes only.

\section{$C K M B$}

Fig. 5 shows the CK MB activities in 18 of the 34 myopericarditis patients (group 1). In only 10 patients, however, was the determination performed during the first six days, at the stage of ST segment elevation. Increases in CK MB occurred only during the first days of the disease; values exceeding the normal upper level 0.03 of the total creatine kinase

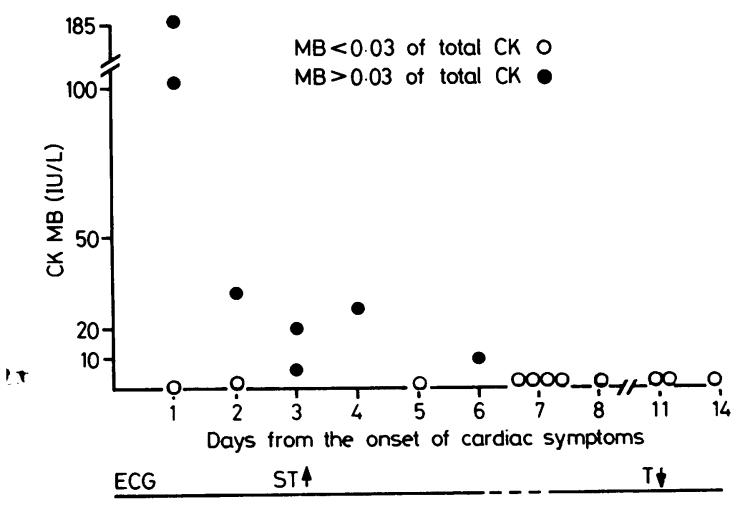

Fig. 5 Serum creatine kinase $M B$ fraction $(C K M B)$ levels studied from 18 patients with myopericarditis (group 1) were abnormal only during the initial days, at the stage of ST segment elevations. were noted in seven patients. These seven patients all had chest pains, initial ST segment elevations, and thereafter deep $T$ wave inversions lasting several weeks (Fig. 6). The highest level, $186 \mathrm{IU} / \mathrm{l}$, was measured in a patient with repetitive bursts of ventricular tachycardia during the first two days of myopericarditis (see Fig. 8). No CK MB abnormalities occurred during the later $\mathrm{T}$ wave inversion stage.

In groups 2 and 3 (myocarditis-type $\mathrm{T}$ wave inversions only) CK MB determinations were available during the first six days of the disease in 28 patients. Only three patients had an activity greater than 0.03 fraction of the total CK level. All CK MB determinations made after the first week of the disease remained negative.

In groups 4 to 7 the $\mathrm{CK} \mathrm{MB}$ activities were determined in 27 patients within six days: they always remained normal.

\section{RECOVERY FROM MYOCARDITIS}

Electrocardiographic abnormalities lasted more than 100 days in only three of the 56 patients in the definite myocarditis groups; 11 patients complained of easy fatigue, tiredness, sharp chest pains, and palpitation when they were re-evaluated six months later. Such symptoms were persistently present in four of 34 patients in group 3, and in four patients in the extrasystolic group. Altogether $16 \cdot 8 \%$ had these symptoms. Notably, the new extrasystoles persisted at this time in 10 of the 14 patients.

\section{Discussion}

\section{ELECTROCARDIOGRAPHIC PATTERNS IN MILD ACUTE MYOCARDITIS}

The clinical diagnosis of myocarditis is often a problem. ${ }^{11}$ This is reflected by such general statements as: "there are no established clinical criteria in the diagnosis of myocarditis", or "the clinical features of viral myocarditis are variable".

Electrocardiographic criteria for acute myocarditis are also vague and non-specific. Most of the difficulties are caused by various ST-T alterations appearing during fever and in subjects showing functional $T$ wave inversions in vasoregulatory lability. ${ }^{7} 1213 \mathrm{In}$ this sense the relevance of the electrocardiographic classification suggested here is discussed below.

\section{Myopericarditis group}

The electrocardiographic pattern of "acute pericarditis" with serially changing ST segment elevations and subsequent $T$ wave inversions is easiest to assess. ${ }^{10}$ The essential role of the myocardial damage itself in causing the characteristic ST-T changes in these patients is pointed out by the ventricular gallop sound 

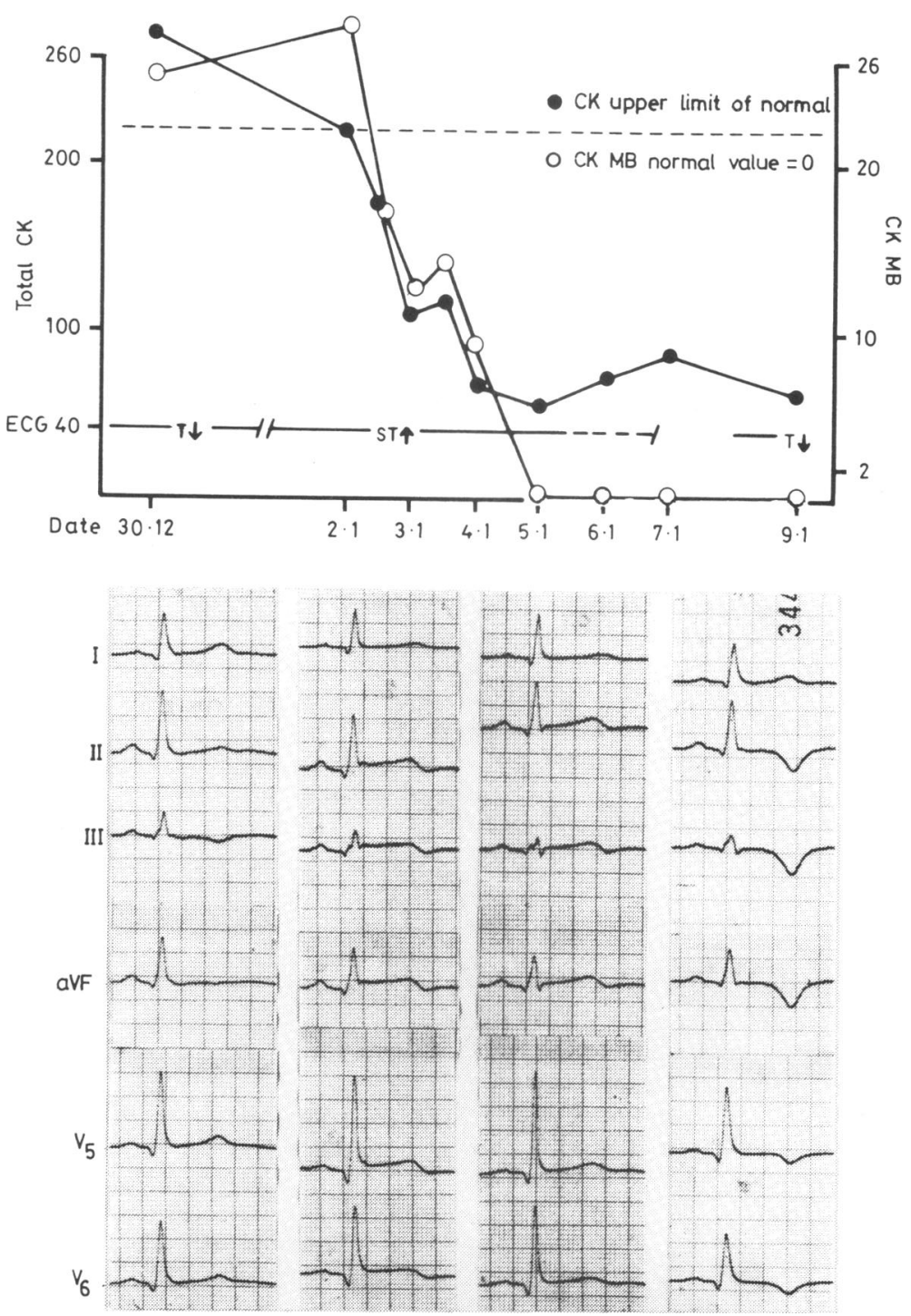

Fig. 6 Serial electrocardiograms from patient with myopericarditis are related to serial total creatine kinase $(C K)$ and $M B$ fraction $(C K M B)$ enzyme levels. On admission the patient had chest pains and negative $T$ waves in inferior leads, followed in a couple of days by pericarditis-type ST segment elevations. Note the very early occurrence of the enzyme elevations, which returned to normal during the first week. CK MB remained abnormal during two days when total creatine kinase had already returned to normal.

and palpable ventricular asynergy, observed in twothirds of our patients in this group. Further, serum enzymes were raised during the first days of the disease, as in acute myocardial infarction. While the ST segment elevations were usually widespread, the subsequent $T$ wave inversions were local, indicating the focal nature of the myocardial damage in mild myocarditis. This conclusion is supported both by our echocardiographic findings on regional left ventricular asynergy ${ }^{8}$ and by recent radionuclide techniques indicating local myocardial damage in Coxsackie and echo virus myocardial disease. ${ }^{14}$ 15 
Myocarditis $T$ wave inversions

The serial $T$ wave inversions in patient groups 2 and 3 were classified as organic changes because of their appearance with acute infection, the gradually changing pattern of the repolarisation changes, and finally their unresponsiveness to beta blockade. Several clinical features indicate that this electrocardiographic manifestation usually reflects a milder degree of myocarditis than is the case in patients with "classic" ST-T patterns. Thus, while the pathological $\mathrm{S}_{3}$ gallop and palpatory cardiac asynergy and pericardial rub were also noted frequently in these patients, they occurred less frequently than they did in group 1 (16 to $39 \%$ ). Myocardial enzyme increases were rare in these patients. Furberg 7 found that the "organic" $T$ wave inversions were not returned to normal by beta blockade. Our series confirms completely his early findings, that is no return to normal, often even worsening, of the $T$ wave inversions.

\section{Recent ventricular extrasystoles}

The following features in the patients with new and electrocardiographically ventricular extrasystoles may indicate underlying acute myocarditis: new appearance in connection with an acute infectious disease, extraordinary fatigue during convalescence, a pathological $\mathrm{S}_{3}$ gallop, and cardiac asynergy on palpation during normal heart beats (in $23 \%$ of this group). In most patients, the ventricular extrasystoles were increased by physical exercise. Cardiac enlargement was noted in the chest $x$-rays of $43 \%$ of these patients, while this change occurred in less than $20 \%$ in all the other groups.

Abnormalities in the upper septal ventricular region may cause only minor electrocardiographic changes, ${ }^{16}$ so that the only evidence of involvement may be arrhythmia. The site of the extrasystoles was indeed most often septal, and our echocardiographic evaluation also usually indicated septal abnormalities, as will be reported separately.

\section{Short-term myocarditis-type $T$ wave inversions}

This group is most difficult to assess: some patients may have minor myocarditis, while others probably have other reasons for the transient nonspecific repolarisation changes, such as functional $T$ wave changes. Though some of the patients may have had minor myocardial involvement, it nevertheless gave

an impression of being clinically insignificant.

Functional $T$ wave changes

"Functional", "vasoregulatory", "vacillating" T wave inversions were characteristically always augmented in the standing position but beta blockade completely restored to normal the $T$ wave inversion. Functional $\mathrm{T}$ wave changes are not uncommon among healthy persons but may inadvertently arouse a suspicion of myocarditis during an acute infection. ${ }^{6} 1317$ Functional $\mathrm{T}$ wave changes also commonly occur during later convalescence after mild myocarditis, ${ }^{18} 19$ as observed also in the present series. In fact, Taggart and co-workers ${ }^{13}$ have reported that the mechanism of the "vasoregulatory" $T$ wave changes is an increased sensitivity of the heart to sympathoadrenergic drive instead of an increased level of circulating catecholamines. Acute myocarditis would thus be one sensitising factor.

\section{SERUM ENZYMES}

This clinical series of acute mild myocarditis is the first documentation of the release of abnormal amounts of $\mathrm{CK} M B$ enzyme in a group of patients. This finding indicates acute myocardial damage. Notably, this occurred at the very initial stage of an acute infection complicated by myocarditis. In the myopericarditis patients, the enzyme leak occurred only during the early phase of the ST segment elevations. The acute myocardial damage in the myopericarditis patients is further disclosed by echocardiographic evidence of clear-cut local myocardial contraction abnormalities. ${ }^{8}$ In myocarditis, the enzyme increases remained smaller than those in acute myocardial infarction, while the release may be somewhat more prolonged, up to six days (Fig. 6 and 7).

Our findings indicate that in mild acute myocarditis the presence and perhaps degree of myocardial damage can be estimated by serial CK MB determinations; most clearly in patients with ST segment elevations (in $70 \%$ of the patients). In patients with myocarditis without an initial ST segment elevation,

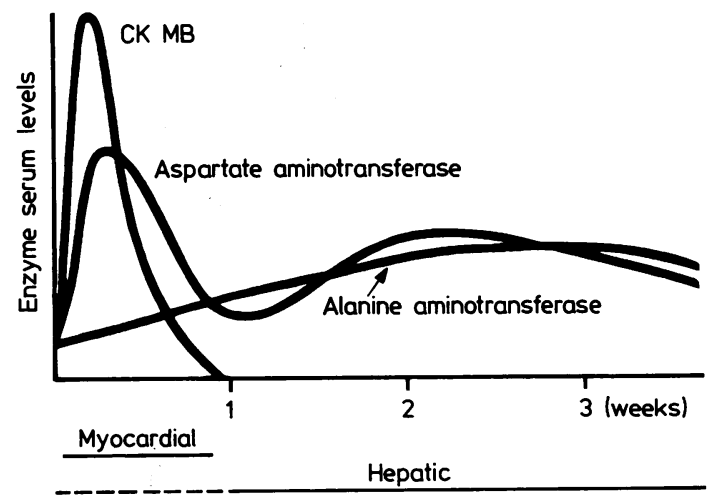

Fig. 7 Characteristic enzyme patterns in viral myocarditis patients. The initial rises indicate myocardial enzyme release. The later secondary peak of aspartate aminotransferase coincides with a rise of alanine aminotransferase, probably indicating persistence of simultaneous hepatic involvement. 

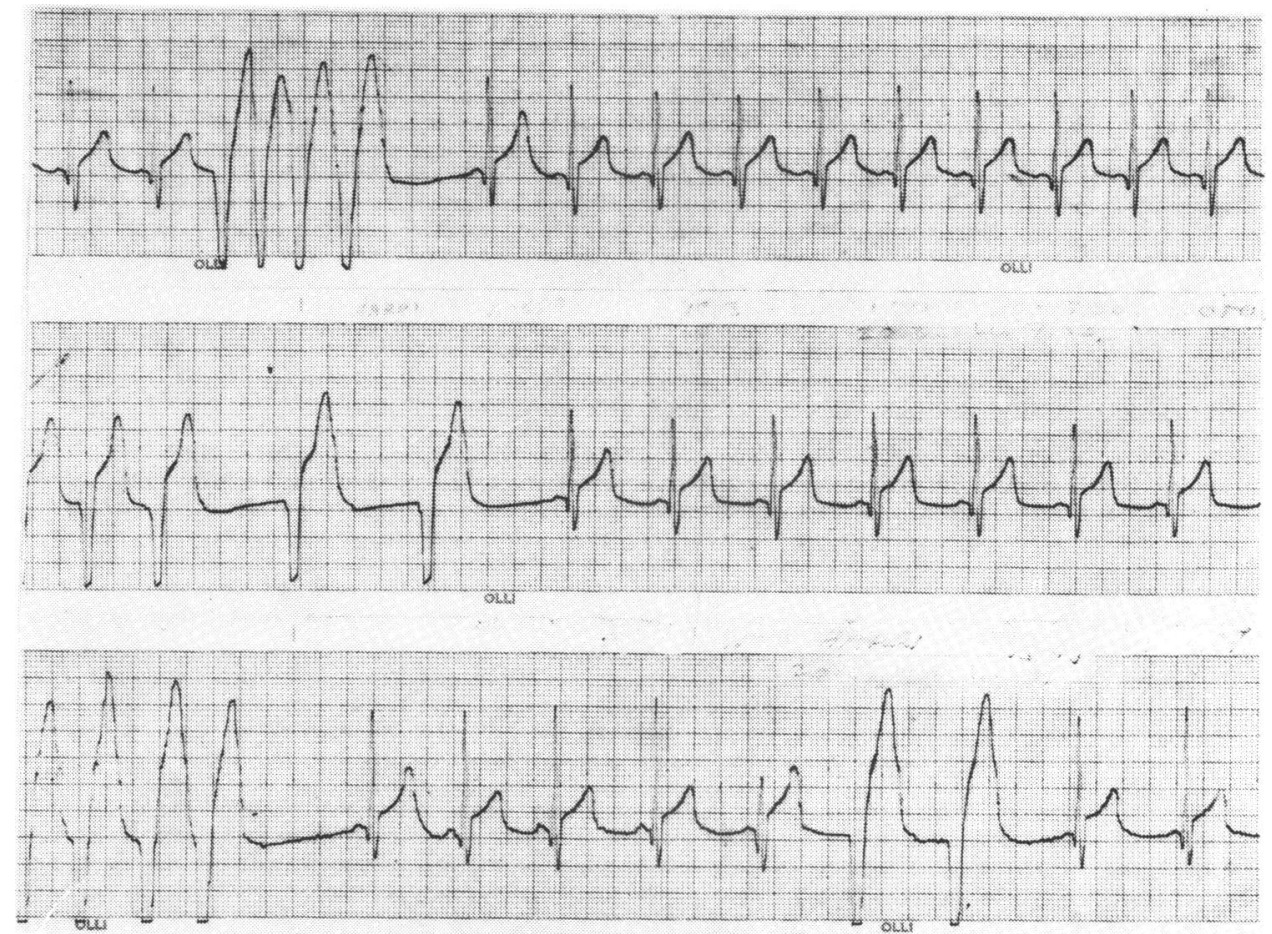

Fig. 8 Repetitive bursts of ventricular tachycardia in a patient with acute myopericarditis. He had severe pericarditis-type chest pains but did not feel any cardiac irregularity. Tachycardias disappeared in two days with procainamide which was administered for one week. CK MB value was 186 IU/l.

the serum CK MB increased in only $10 \%$ of the patients, probably indicating only minor myocardial pathology. In addition to an increase in $\mathrm{CK} M B$, the serum aspartate aminotransferase is often also increased in patients with myopericarditis, again at the initial stage of ST segment elevation. High values, however, were often noted at the later stage as well, when CK MB was normal. In these patients there was always a simultaneous increase in alanine aminotransferase, the obvious cause being hepatocellular damage (Fig. 7). Thus, viral myocarditis may often be accompanied by slight hepatitis, a well-known example being infectious mononucleosis.

On the basis of these data we propose that enzyme diagnostics be performed serially at the very initial stage of suspected myocarditis, as is the case with patients with acute myocardial infarction.

\section{CLINICAL CORRELATIONS AND IMPLICATIONS}

The general view is that myopericarditis usually develops one to two weeks after the onset of an acute respiratory infection. ${ }^{20}$ The close follow-up of most patients in our series, however, clearly indicates that clinical, electrocardiographic, myocardial enzymatic, and echocardiographic signs of myocardial involve- ment are present from the first days of a viral infection. In the majority of the patients, myocardial damage was local. This course of the disease reflects a direct and often local viral invasion of the myocardium, ${ }^{121}$ instead of immunopathogenetic mechanisms. Certainly, the latter mechanism may contribute later to a persisting disease state in some patients. ${ }^{1}$ Further, mild myocarditis was usually completely cured in a few weeks to months.

In our experience, the characteristic electrocardiogram of "acute pericarditis" seems to reflect the very initial stage of myocarditis. In fact, our data indicate that myocardial damage in viral myopericarditis seems to be the basic pathology, not "isolated" pericarditis. In the presence of pericarditis the diagnosis of underlying myocarditis may be overlooked; the latter is suggested by the presence of clinical and echocardiographic ventricular asynergy, $\mathrm{S}_{3}$ gallop, subsequent local $T$ wave inversions, and early enzyme release. The concomitant pericarditis may actually be a secondary irritation of the subepicardial myocardial lesion, as is the case in acute myocardial infarction.

Even in mild acute myocarditis serious cardiac arrhythmias, that is atrioventricular block or ventricular tachycardia, are possible. These arrhythmias 
may predict sudden death in myocarditis. Though rare, ${ }^{3}$ this possibility of a serious complication warrants the careful observation of these patients during the first days of the disease (Fig. 8), and an avoidance of physical exercise during this period. ${ }^{22}$

The patients in this study population recovered quickly, with only a few exceptions. In reports of similar patients, the long-term prognosis is good. ${ }^{18} 19$ The pathogenesis of severe and fatal myocarditis, leading to intractable heart failure and pronounced histological inflammatory changes, ${ }^{423} 24$ seems to be different from that of acute mild myocarditis. Continuing long-term clinical and echocardiographic follow-up will reveal if any of these patients with mild myocarditis will later develop chronic congestive cardiomyopathy.

The use of corticosteroids has aggravated experimental viral myocarditis. ${ }^{25}$ Corticosteroids would therefore be contraindicated in the acute stage of viral uncomplicated myocarditis. Instead, other non-steroidal anti-inflammatory drugs can be used successfully and more safely to relieve pericardial pain. We did not use steroids in this series, and neither did we see progressive deterioration of cardiac involvement.

\section{References}

1 Wynne J, Braunwald E. Infectious myocarditis. In: Braunwald E, ed. Heart disease. Philadelphia: WB Saunders, 1980: 1472-89.

2 Lewes D, Rainford DJ, Lane WF. Symptomless myocarditis and myalgia in viral and Mycoplasma pneumoniae infections. Br Heart $\mathcal{F}$ 1974; 36: 924-32.

3 Koskenvuo K. Sudden deaths among Finnish conscripts. Br Med f 1976; ii: 1413-5.

4 Kawai C, Matsumori A, Kitaura Y, Takatsu T. Viruses and the heart: viral myocarditis and cardiomyopathy. In: Yu PN, Goodwin JF, eds. Progress in cardıology. Vol. 7. Philadelphia: Lea \& Febiger, 1978: 141-62.

5 Karjalainen J, Nieminen MS, Heikkilä J. Influenza A1 myocarditis in conscripts. Acta Med Scand 1980; 207: 27-30.

6 Levine HD. Virus myocarditis: a critique of the literature from clinical, electrocardiographic, and pathologic standpoints. Am F Med Sci 1979; 277: 132-43.

7 Furberg C. Adrenergic beta-blockade and electrocardiographical ST-T changes. Acta Med Scand 1966; 181: 21-32.

8 Nieminen MS, Heikkilä J. Echocardiographic features of acute myocarditis (abstract). In: 3rd symposium on echocardiology. Rotterdam: European Society of Cardiology (transactions), 1979: 68.

9 Somer H, Konttinen A. A method allowing the quantitation of serum creatine kinase isoenzymes. Clin Chim Acta 1972; 36: 531-6.

10 Spodick DH. Electrocardiogram in acute pericarditis. Distribution of morphologic and axial changes by stages. Am $\mathcal{F}$ Cardiol 1974; 33: 470-4.

11 Abelmann WH. Virus and the heart. Circulation 1971; 44: $950-6$.

12 Friman G. Effects of acute infectious disease on circulatory function. Acta Med Scand 1976; suppl 592.

13 Taggart P, Carruthers M, Joseph S, et al. Electrocardiographic changes resembling myocardial ischaemia in asymptomatic men with normal coronary ateriograms. $\mathrm{Br}$ Heart $f$ 1978; 41: 214-25.

14 Desa'neto A, Bullington JD, Bullington RH, Desser $\mathrm{KB}$, Benchimol A. Coxsackie B5 heart disease. Demonstration of inferolateral wall myocardial necrosis. Am $\mathcal{F}$ Med 1980; 68: 295-8.

15 Miklozek CL, Parker JA, Royal HD, Come PC, Modlin JF, Abelmann WH. Radionuclide ventriculography in viral myopericarditis patients (abstract). Circulation 1980; 62, suppl III: 318.

16 Sodi-Pallares D, Bisteni A, Cisneros F, deMicheli A, Medrano GA, Testelli MR. Reliability of the electrocardiogram in diagnosis of myocardial infarction. In: Likoff W, Moyer JH, eds. Coronary heart disease. New York: Grune \& Stratton, 1963: 278-94.

17 Atterhög J-H. A 5-year follow-up of young men with primary $\mathrm{T}$ wave aberrations in their electrocardiograms. Acta Med Scand 1981; 209: 75-82.

18 Bengtsson E, Lamberger B. Five-year follow-up study of cases suggestive of acute myocarditis. Am Heart $\mathcal{F}$ 1966; 72: 751-63.

19 Gerzén P, Granath A, Holmgren B, Zetterquist S. Acute myocarditis. A follow-up study. $\mathrm{Br}$ Heart $\mathcal{f}$ 1972; 34: 575-83.

20 Burch GE, Giles TD. The role of viruses in the production of heart disease. Am $\mathcal{F}$ Cardiol 1972; 29: 231-40.

21 Woodruff JF. Viral myocarditis. A review. Am $\mathcal{f}$ Pathol 1980; 101: 427-84.

22 Gatmaitan BG, Chason JL, Lerner AM. Augmentation of the virulence of the murine Coxsackie virus B-3 myocardiopathy by exercise. $\mathcal{F}$ Exp Med 1970; 131: 1121-36.

23 Gardiner AJS, Short D. Four faces of acute myopericarditis. Br Heart F 1973; 35: 433-42.

24 Mason JW, Billingham ME, Ricci DR. Treatment of acute inflammatory myocarditis assisted by endomyocardial biopsy. Am $\mathcal{F}$ Cardiol 1980; 45: 1037-44.

25 Kilbourne ED, Wilson CB, Perrier D. The induction of gross myocardial lesions by a Coxsackie (pleurodynia) virus and cortisone. $\mathcal{f}$ Clin Invest 1956; 35: 362-70.

Requests for reprints to Dr Juhani Heikkilä, Cardiovascular Laboratory, University Central Hospital, SF-00290 Helsinki 29, Finland. 